\title{
Caprella mutica in the Southern Hemisphere: Atlantic origins, distribution, and reproduction of an alien marine amphipod in New Zealand
}

\author{
Kate J. Willis ${ }^{1, *}$, Chris M. C. Woods ${ }^{1}$, Gail V. Ashton ${ }^{2}$ \\ ${ }^{1}$ National Institute for Water and Atmospheric Research, PO Box 8602, Riccarton, Christchurch, New Zealand \\ ${ }^{2}$ Smithsonian Environmental Research Centre, 3150 Paradise Drive, Tiburon, California 94920, USA
}

\begin{abstract}
The caprellid amphipod Caprella mutica, a native of northeast Asia, was first detected in the Southern Hemisphere in the Port of Timaru, New Zealand, in 2002. It has since become established in the Port of Lyttelton and at 2 aquaculture sites in the Marlborough Sounds in New Zealand. Direct sequencing of $C$. mutica mitochondrial DNA (cytochrome $c$ oxidase subunit I gene) identified 3 haplotypes: 1 unique to New Zealand and 2 previously found in non-native Atlantic populations. Higher haplotype diversity and lower $F_{\mathrm{ST}}$ distances between the Port of Lyttelton and global populations suggest Lyttelton may be the introduction site in New Zealand. C. mutica populations were sampled on 7 occasions, primarily in winter, and densities generally exceeded 10000 ind. $\mathrm{m}^{-2}$, contrasting with the winter declines seen in native and European populations. Sex ratios were generally close to 0.5 and the proportion of brooding females ranged from 0 to $98 \%$. In the Marlborough Sounds, juveniles comprised 32 to $38 \%$ of the population regardless of season, brooding females were present throughout the year and males were dominant in winter. Population structure and adult size in the Port of Lyttelton differed with habitat type in August 2008; densities were higher, adults significantly larger on floating than on fixed structures and juveniles and brooding females dominated on vessel hulls. Given the high level of anthropogenic activity and connectivity between coastal locations, it is likely that C. mutica will continue to spread in New Zealand.
\end{abstract}

KEY WORDS: Caprellid amphipod · Bioinvasion · COI gene $\cdot$ Population genetics $\cdot$ Population biology Dispersal $\cdot$ Hull fouling

\section{INTRODUCTION}

The caprellid amphipod Caprella mutica Schurin, 1935 is indigenous to sub-boreal waters of northeast Asia (Peter the Great Bay, Vladivostok, Russia) and was identified from Possjet Bay, Russia (Vassilenko 1967) and Akkeshi Bay, Japan (Arimoto 1976). The first reports of C. mutica outside its native habitat were from the Pacific and Atlantic coasts of North America in the 1970s (Carlton 1979) and 1980s (Marelli 1981, Cohen \& Carlton 1995). Reviews of its global distribution indicate that, in the last $40 \mathrm{yr}, C$. mutica has spread throughout the northern hemisphere along the coasts of Europe, North America and Canada (Ashton et al. 2007, Cook et al. 2007, Frey et al. 2009). Dispersal of C. mutica within
Europe has been rapid and represents a range extension of $\sim 1200 \mathrm{~km}$ along the west coast of Norway and $\sim 1000 \mathrm{~km}$ to the west coast of Ireland (Cook et al. 2007) from its first recorded location in The Netherlands in 1995 (Platvoet et al. 1995). Ashton et al. (2008a) reported the presence of $C$. mutica in the Aleutian Islands of Alaska, where it may have been present since at least 2002. C. mutica is the first reported non-indigenous marine species (NIMS) in the Aleutian Archipelago (Ashton et al. 2008a). The global distribution of C. mutica can be attributed to shipping, aquaculture activities and recreational boating, with localised dispersal on drifting macroalgae (Ashton 2006). Carlton (1979) suggested that C. mutica arrived on the Pacific and Atlantic coasts of North America either as a result of numerous, indepen- 
dent cross-oceanic introductions with oyster spat, or from small-scale transport following its first introduction (Carlton 1996). Direct sequencing of mitochondrial DNA indicates that $C$. mutica was introduced to Europe either directly from Asia or from the Atlantic coast of North America (Ashton et al. 2008b). The presence of haplotypes common to both Atlantic coastlines indicates transAtlantic transport routes and/or the same source populations. Non-native populations on the Pacific coast of North America are genetically distinct, indicating a route of introduction independent from that of the Atlantic (Ashton et al. 2008b).

In non-native European and Canadian populations on artificial structures, densities in excess of 10000 ind. $\mathrm{m}^{-2}$, in summer (Boos 2009, Frey et al. 2009, Ashton et al. in press), are considerably higher than those reported from natural near-bottom habitat in Caprella mutica's native range in northeast Asia (Fedotov 1991, Vassilenko 2006). During winter in native and European populations, reproduction is curtailed and population densities are significantly reduced or possibly absent in some locations.
The development of a surveillance programme for NIMS in New Zealand by the Ministry of Fisheries Biosecurity New Zealand, with the first baseline surveys undertaken in 2001, has provided a unique opportunity to establish a baseline distribution of Caprella mutica. Since the baseline surveys, its spread has been monitored during regular biosecurity activities in ports and marinas throughout New Zealand, and opportunistically through other aquaculture-related research. We present information on the distribution, origins and population biology of C. mutica in New Zealand.

\section{MATERIALS AND METHODS}

Distribution of Caprella mutica in New Zealand. To establish the baseline distribution of C. mutica in New Zealand ports and marinas, we reviewed the species lists in the baseline survey reports for 13 ports and 3 marinas surveyed between 2001 and 2005 for native and non-native marine species (Fig. 1a). Records of the

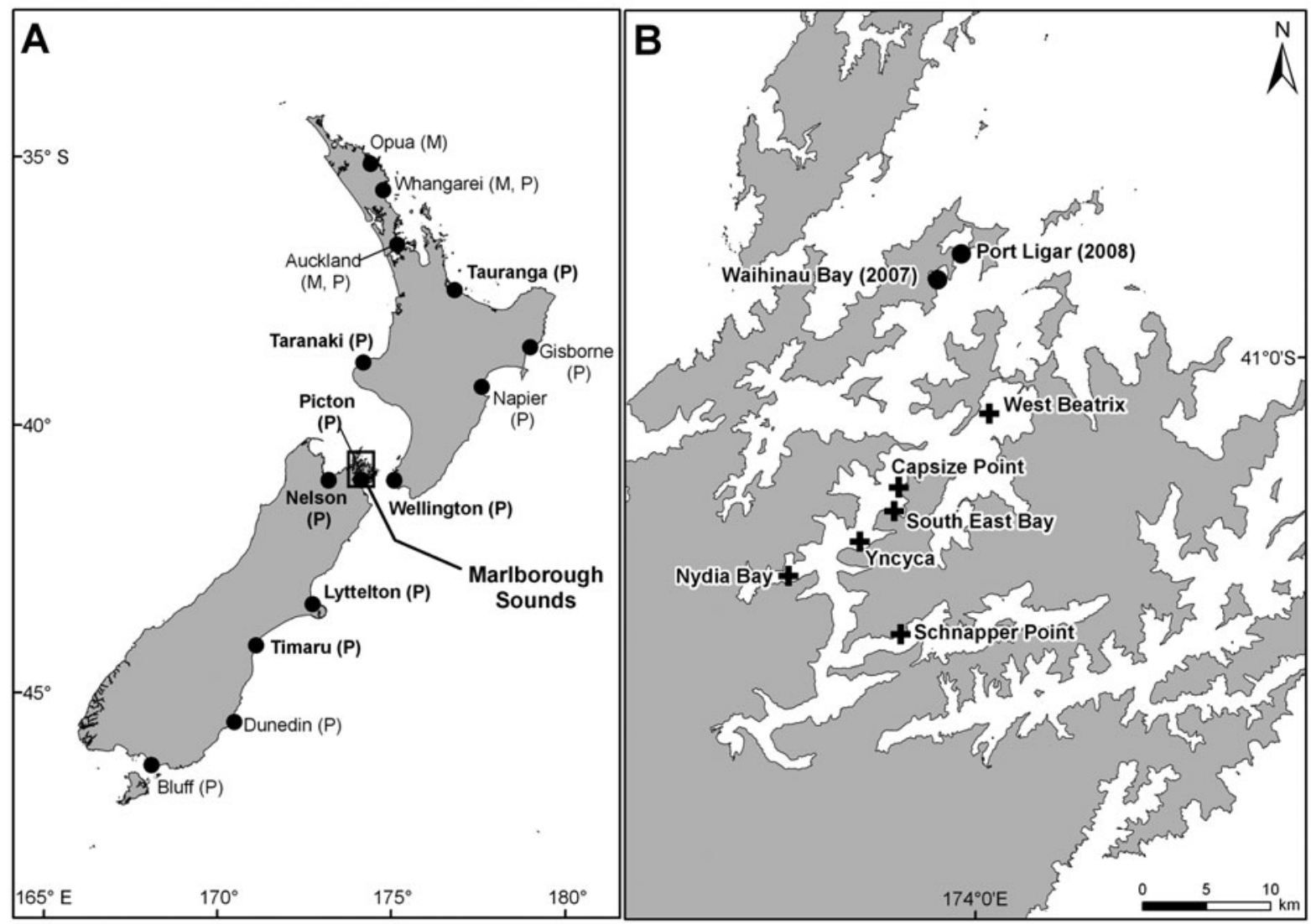

Fig. 1. (A) Commercial shipping ports (P) and marinas (M) in New Zealand where baseline surveys for native and non-native species have been conducted. Ports surveyed in summer 2001-2002 and resurveyed in summer 2004-2005 are indicated in bold; those surveyed in summer 2002-2003 are indicated in plain text. Marinas at Auckland, Opua and Whangarei were surveyed in 2002-2003. (B) Distribution of marine farm biofouling sampling stations in Pelorus Sound, Marlborough Sounds, New Zealand.

(•) Positive recordings of Caprella mutica (year of first detection); (+) negative recordings 
presence of $C$. mutica in the Port of Lyttleton are reported from ongoing surveillance programmes for NIMS in ports and marinas around New Zealand. In the Marlborough Sounds, the presence or absence of C. mutica is reported from aquaculture sites visited during research investigating fouling development on and around Greenshell ${ }^{\mathrm{TM}}$ mussel farms in 2007 and 2008 (Fig. 1b).

Origins and dispersal. Specimens of Caprella mutica, collected in April 2008 from floating tyre fenders in the Port of Lyttelton in June 2008 and from mussel lines in Waihinau Bay, Marlborough Sounds, were immediately preserved in 99\% ethanol. Individuals were confirmed to be C. mutica (Arimoto 1976) by stereomicroscope. DNA was extracted from whole animals using a Qiagen BioSprint 96 DNA Blood Kit. All genetic analysis was conducted at the Smithsonian's Laboratories of Analytical Biology in Suitland, Maryland, USA.

A 550 bp fragment of the mitochondrial cytochrome c oxidase subunit I (mtDNA COI) gene was amplified using the primers COI4F (5'-AAC AYY TAT TYT GAT TCT TTG GTC ACC C-3') and COI2R (5'-GGR TAR TCW GAR TAW CGN CGA GGT ATC CC-3') (modified from Ashton et al. 2008b). The PCR (Saiki et al. 1988) was run on an MJ Research Tetrad Thermal Cycler (Bio-Rad Laboratories). The $10 \mu \mathrm{l}$ reaction volume consisted of $1 \mu \mathrm{l}(\sim 20$ to $50 \mathrm{ng})$ DNA, $1 \times$ PCR buffer (BioLine), $1.5 \mathrm{mM} \mathrm{MgCl}_{2}$ (BioLine), $0.5 \mathrm{mM}$ deoxynucleoside triphosphate (dNTP) mix (BioLine), $0.3 \mu \mathrm{M}$ of each primer and $0.5 \mathrm{U}$ Taq DNA polymerase (BioLine). Thermal cycling conditions were: $95^{\circ} \mathrm{C}$ for 5 min followed by 35 cycles of denaturation at $95^{\circ} \mathrm{C}$ for $30 \mathrm{~s}$, annealing at $52^{\circ} \mathrm{C}$ for $30 \mathrm{~s}$ and extension at $72^{\circ} \mathrm{C}$ for $45 \mathrm{~s}$, followed by a final extension at $72^{\circ} \mathrm{C}$ for $3 \mathrm{~min}$ (modified from Witt \& Hebert 2000).

Agarose gel electrophoresis using SYBR stain (Invitrogen) was used to visualise PCR products, which were then purified using ExoSAP-IT (USB). A volume of

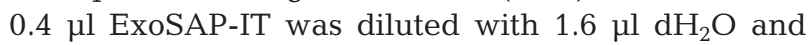
added to $8.0 \mu \mathrm{l}$ PCR product. Samples were heated to $37^{\circ} \mathrm{C}$ for $30 \mathrm{~min}$ followed by $20 \mathrm{~min}$ at $80^{\circ} \mathrm{C}$ and cyclesequenced using BigDye ${ }^{\mathrm{TM}}$ Terminator v3.1 (Applied Biosystems). Cycle-sequencing reactions contained $1 \mu \mathrm{l}$ cleaned PCR product, $0.5 \mu \mathrm{l}$ BigDye, $1.75 \mu \mathrm{l}$ cyclesequencing buffer, $0.5 \mu \mathrm{l}$ COI4F primer and $6.25 \mu \mathrm{l}$ $\mathrm{dH}_{2} 0$. Thermal cycling conditions were 25 cycles of $96^{\circ} \mathrm{C}$ for $10 \mathrm{~s}, 50^{\circ} \mathrm{C}$ for $5 \mathrm{~s}$ and $60^{\circ} \mathrm{C}$ for $4 \mathrm{~min}$. Reactions were cleaned using Sephadex G-50 (Sigma-Aldrich) and loaded onto a 3730xl DNA analyzer (Applied Biosystems) with a $36 \mathrm{~cm}$ array.

The resulting 38 sequences were verified as Caprellidae DNA using the GenBank ${ }^{\mathrm{TM}}$ BLASTn search (Altschul et al. 1990). The sequences from New Zealand were analysed along with published sequences of Caprella mutica from its native and non-native range
(GenBank accession nos. DQ466220-466523; Ashton et al. 2008b). Novel unique sequences were deposited with GenBank. C. equilibra and C. acanthogaster (accession nos. DQ466519-466521) were used as outgroups for the phylogenetic analyses. Sequences were edited and aligned using Sequencher 4.8 (Gene Codes) and trimmed to a length of $533 \mathrm{bp}$.

Modeltest 3.7 (Posada \& Crandall 1998) was used to determine the appropriate model parameters for maximum likelihood (ML) analysis in PAUP* 4.0b10 (Swofford 2002). The Hasegawa-Kishino-Yano + gamma $(\Gamma)$ model $(-\ln \mathrm{L}=1889.5066$ [AIC]; base frequencies set to $\mathrm{A}=0.3684, \mathrm{C}=0.1674, \mathrm{G}=0.2062, \mathrm{~T}=0.2580$; transition/tranversion $(\mathrm{Ti} / \mathrm{tv})$ ratio $=6.2804 ;$ gamma correction $=0.1573$ ) was found to be the best fit to the data; all other options in PAUP* remained as default for the ML heuristic analyses. Bayesian analysis was implemented using MrBayes v.3.1.2 (Ronquist \& Huelsenbeck 2003). ML bootstrap analyses were conducted with 500 replicates (Felsenstein 1985) using the same settings as the heuristic search in GARLI (Zwickl 2006). Arlequin 3.0 (Excoffier et al. 2005) was used to calculate pairwise $F_{\mathrm{ST}}$ measures between sites. Total variation within the non-native populations was analysed by including all geographically isolated populations independently in an analysis of molecular variance (AMOVA).

Population biology. Individuals of Caprella mutica were collected from between 0 and $5 \mathrm{~m}$ depth on 7 occasions between December (summer) 2006 and August (winter) 2008 (Table 1) from boat hulls, fixed mooring piles and floating tyre fenders in Magazine Bay Marina in Lyttleton Harbour (December 2006) and the Port of Lyttelton (June, August and November 2008) during routine SCUBA surveillance surveys for NIMS. C. mutica were also collected from between 0 and $5 \mathrm{~m}$ depth from mussel lines in Waihinau Bay in the Marlborough Sounds (May and August 2007 and February 2008) during servicing of submerged experimental structures. The presence/absence of $C$. mutica at 6 mussel farms in the Marlborough Sounds was monitored during bi-monthly SCUBA surveys of fouling development between February 2007 and May 2008 (Fig. 1b).

At sites where Caprella mutica were present, approximately $15 \times 15 \mathrm{~cm}\left(225 \mathrm{~cm}^{2}\right)$ of the fouling substratum was scraped from the base substratum by SCUBA divers into plastic Ziploc ${ }^{\circledR}$ bags, which were then sealed and frozen for later analysis. Abundance (number of caprellids per $\mathrm{m}^{2}$ scaled up from the $225 \mathrm{~cm}^{2}$ sample) and biomass (wet weight [WW] and dry weight [DW; dried at $60^{\circ} \mathrm{C}$ for $48 \mathrm{~h}$ ] in $\mathrm{g} \mathrm{m}^{-2}$ ) were determined for each site and sampling time. Biomass (DW) of the fouling substratum was determined for samples collected from the Port of Lyttelton on 27 August 2008. 


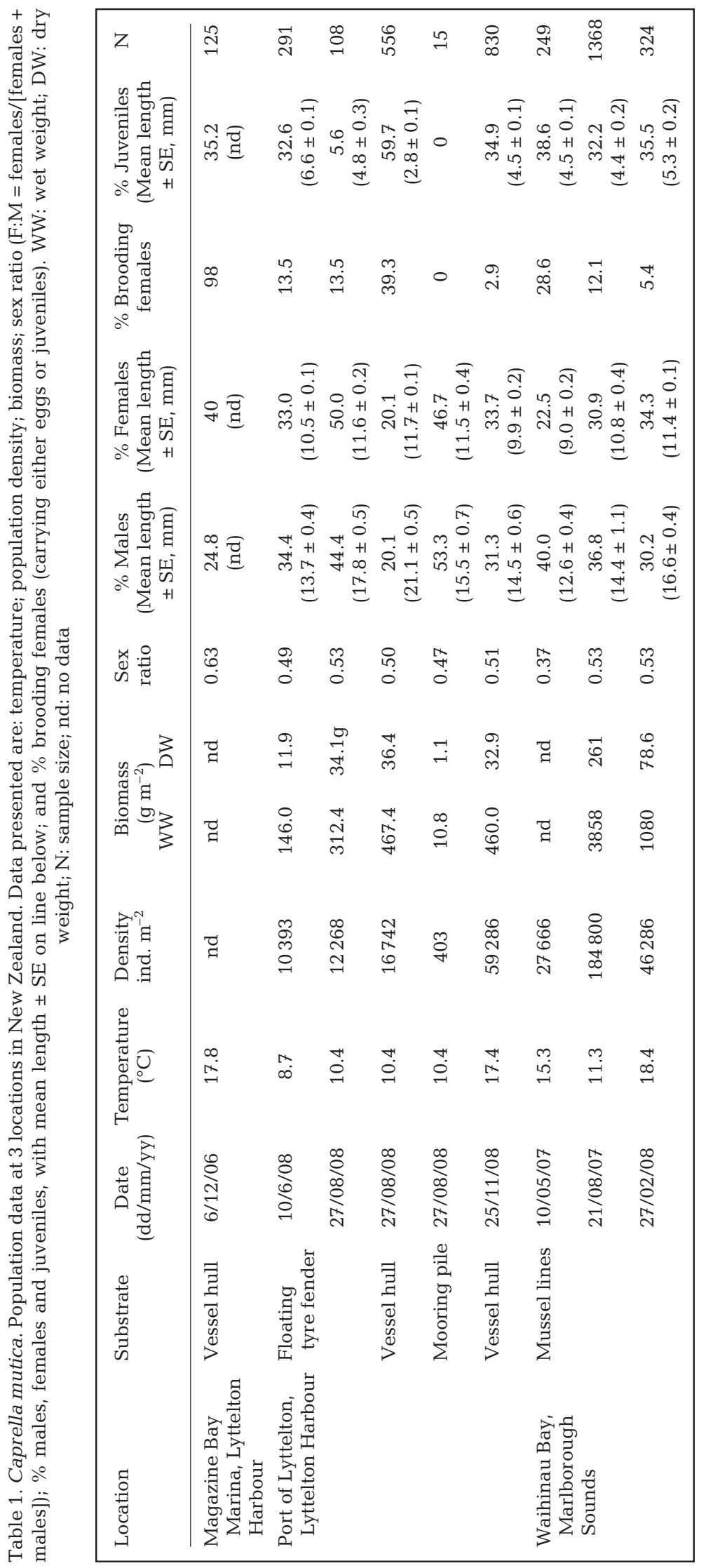

Body dimensions of individuals from each site ( $\mathrm{n}=15$ to 1368 , Table 1 ) were measured to the nearest $0.1 \mathrm{~mm}$ with a calibrated eyepiece micrometer in a WILD stereomicroscope. Body length was measured from the front of pereonite I (head) to the end of pereonite VII. Females were identified by the presence of oostegites, the anterior position of gnathopod II and a lack of setation on pereonites I and II, and males by the distal position of gnathopod II and extension and setation of pereonites I and II (Arimoto 1976, Laubitz 1970). Juveniles were defined as individuals $<4 \mathrm{~mm}$ long or lacking characteristics of either sex. To determine the relationship between female body length and fecundity, eggs dislodged from 47 females (frozen) from Port Lyttelton (June and August 2008) and the Marlborough Sounds (May 2007 and February 2008) were counted after removal from the brood pouches within $2 \mathrm{~d}$ of collection.

Statistical analyses of differences in caprellid body length and brood size between sample locations were conducted with Number Crunching Statistical Software (NCSS 2004, www.ncss.com). Differences in caprellid length between different substrata in Lyttelton Harbour on 27 August 2008 were tested with 1-way ANOVA with a priori testing for homogeneity and post hoc Tukey-Kramer tests where significant differences in means were detected $(p<0.05)$. Differences in total body length between the sexes were tested with Student's $t$-tests for adult caprellids collected from the Port of Lyttelton and the Marlborough Sounds. The relationship between female body length and fecundity was tested with Kendall's $\tau$.

\section{RESULTS}

\section{Distribution of Caprella mutica in New Zealand}

A baseline distribution for Caprella mutica in New Zealand derived from surveys of 13 ports and 3 marinas for NIMS between 2001 and 2005 suggest that this caprellid was only recently introduced to New Zealand's coastal waters. During the baseline port surveys, C. mutica was detected only in the Port of Timaru (Fig. 1a). Since then, the caprellid was found in the Port of Lyttelton (Fig. 1a) and at 2 

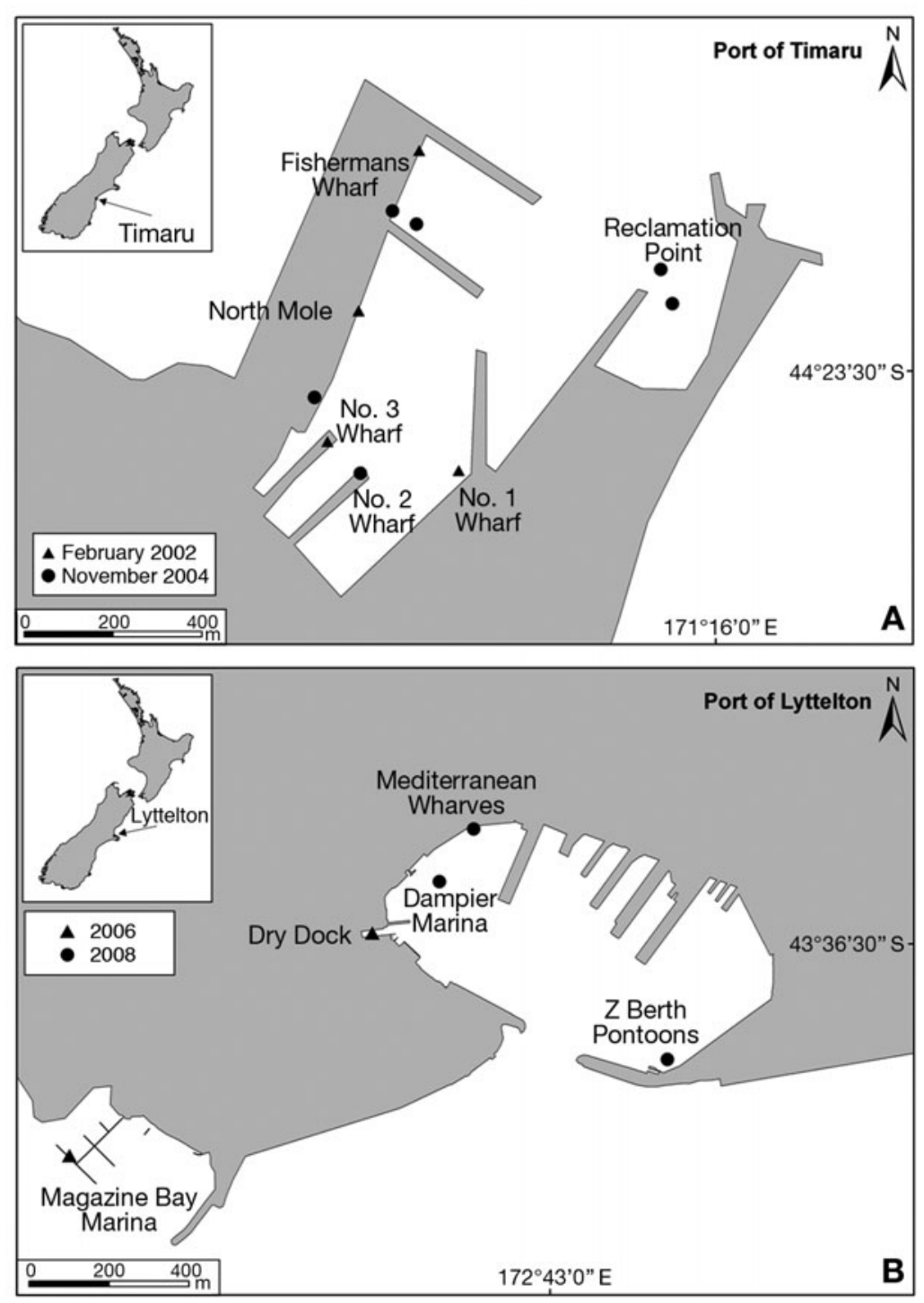

Fig. 2. Caprella mutica. Distribution of C. mutica in (A) the Port of Timaru in the 1st (February 2002) and 2nd (November 2004) baseline surveys for native and non-native marine species (Inglis et al. 2006a), and (B) the Port of Lyttelton and Magazine Bay Marina, including years of detection (2006 or 2008)

aquaculture sites in the Marlborough Sounds (Fig. 1b). Therefore, C. mutica in New Zealand currently is restricted to 4 known locations in the South Island.

\section{Timaru}

Specimens collected from the Port of Timaru in February 2002 during the first baseline survey for NIMS in New Zealand comprised the first record of this species in New Zealand and the Southern Hemisphere (Inglis et al. 2006a). At that time, Caprella mutica occurred in pile scrape samples taken from Wharf Nos. 1 and 3,
Fisherman's Wharf and North Mole (Fig. 2a). In a second baseline survey in November 2004, the caprellid occurred in pile scrape samples taken from North Mole, Fisherman's Wharf and Wharf No. 2, and in benthic sled samples from Inner North Mole and Reclamation Point (Fig. 2a) (Inglis et al. 2006a).

\section{Lyttelton}

Baseline surveys in the Port of Lyttelton in March 2002 and November 2004 (Inglis et al. 2006b) did not detect Caprella mutica, suggesting its absence at that time. C. mutica was first discovered in Lyttelton in low numbers in the seachest of a commercial fishing trawler opened up for water-blasting during routine maintenance in Lyttelton's dry dock (Fig. 2b) on 20 April 2006 (C. M. C. Woods unpubl. data). Subsequently, it was observed by SCUBA divers amongst extensive hull-fouling on a private launch on 5 December 2006 in Magazine Bay Marina (Fig. 2b). Within the Port of Lyttelton, C. mutica was first observed on submerged fouling biota on floating moorings on 10 June 2008 at the Mediterranean Wharves by SCUBA divers (Fig. 2b). In August 2008, C. mutica was found to be present amongst hull-fouling on 27 out of 67 recreational vessels ( $40 \%$ colonisation) at Dampier Marina, which is located within the port, and on 5 out of 17 coastal fishing vessels ( $29 \%$ colonisation) at the Mediterranean Wharves during SCUBA diver inspections of moored vessels. In late November 2008, C. mutica was observed on the submerged surfaces of floating pontoons at the Z-berth by SCUBA divers.

\section{Marlborough Sounds}

In May 2007, Caprella mutica was observed at depths of 0 to $5 \mathrm{~m}$ on numerous commercial (mussel long lines), public (swing moorings) and experimental moored structures in Waihinau Bay (Fig. 1b), Pelorus Sound, in close proximity to a commercial salmon farm. In February 2008, C. mutica was detected on commercial (mussel long lines) and experimental moored structures in nearby Port Ligar (Fig. 1b). Both these sites are in the outer Marlborough Sounds. $C$. 


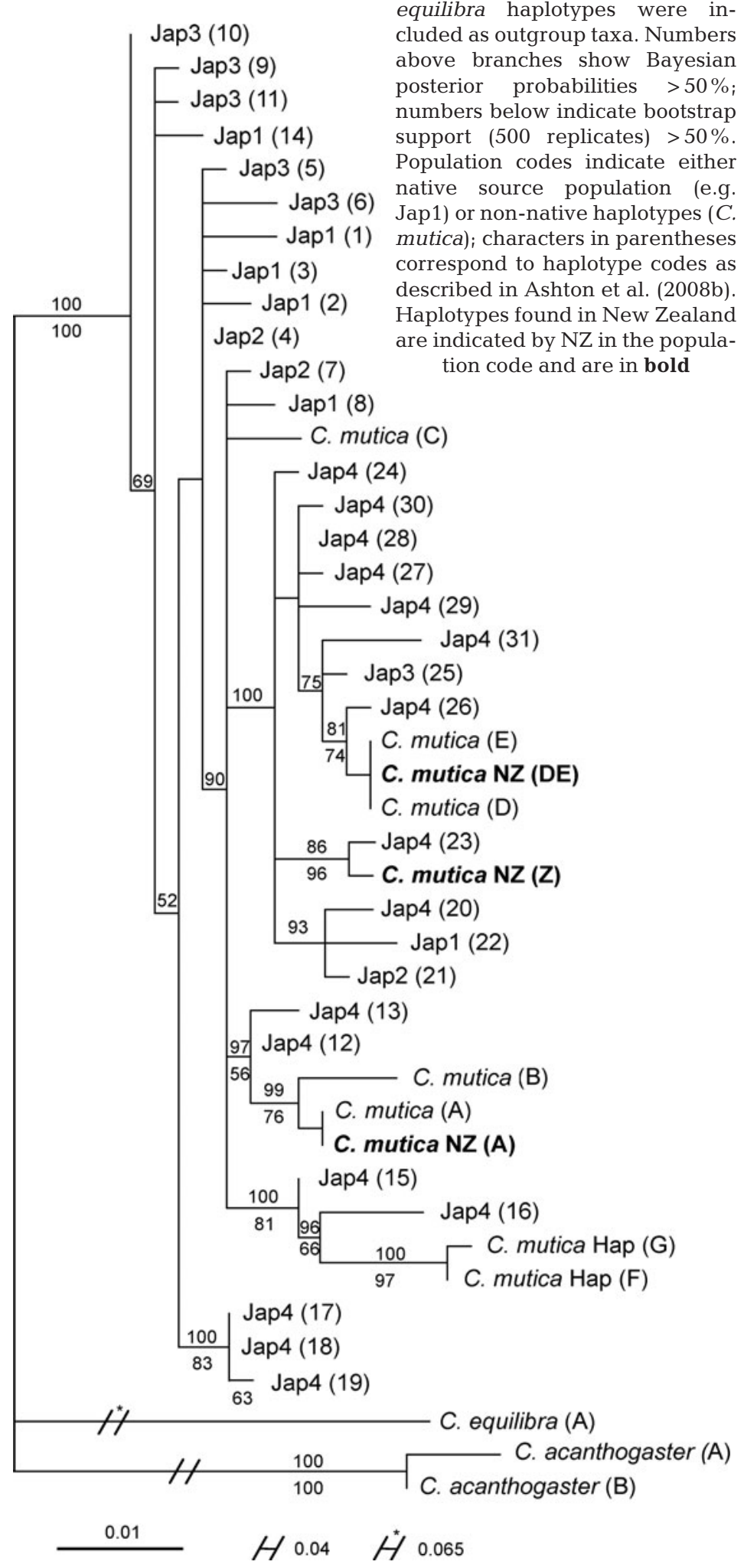
cluded as outgroup taxa. Numbers above branches show Bayesian posterior probabilities $>50 \%$ numbers below indicate bootstrap support (500 replicates) $>50 \%$. Population codes indicate either native source population (e.g. Jap1) or non-native haplotypes ( $C$. mutica); characters in parentheses Haplotypes found in New Zealand indicated by NZ in the popula-
Fig. 3. Caprella mutica. Phylogeny of $C$. mutica from its native and non-native range, constructed using a Bayesian phylogenetic approach. C. acanthogaster and $C$. equilibra haplotypes were in-

\section{(1)} lations ( $h>0.620, \pi>0.009$ ), but similar to that of introduced populations on northern Atlantic and Pacific coasts (Ashton et al. 2008b).

Two of the New Zealand haplotypes were also observed in North Atlantic populations; a single haplotype was novel and most similar to a haplotype observed in a native Japanese population (Fig. 3). The novel haplotype (haplotype Z) included a single additional variable site at the third codon position (accession no. FJ705624). Haplotype Z was found in both Marlborough and Lyttelton in New Zealand (Fig. 4). Of the 2 haplotypes sequenced previously, haplotype A (which was widespread throughout the Atlantic) was only found in Lyttelton, while haplotype DE (this covers 2 previously defined haplotypes, the fragment sequenced here was not able to distinguish between haplotype D found only in Scotland and haplotype E found only in east Canada) was found at both sites (Fig. 4). Population pairwise $F_{\mathrm{ST}}$ distances between NZMarl and other native and non-native sites were greater than those for NZLytt (Table 2).

\section{Population biology}

Population densities of non-native Caprella mutica in New Zealand ranged from 403 caprellids $\mathrm{m}^{-2}$ on a pile mooring in the Port of Lyttelton in August 2008 to $184800 \mathrm{~m}^{-2}$ on mussel lines at a salmon farm in the Marlborough Sounds in August 2007 (Table 1). The biomass (WW) at these 2 sites was 10.75 and $3858 \mathrm{~g} \mathrm{~m}^{-2}$, respectively (Table 1). The ratio of females to males was generally close to 0.5 , with males slightly more abundant than females on more than half of the sampling occasions. Males dominated the population at Waihinau Bay in June 2007, while females dominated the population in 

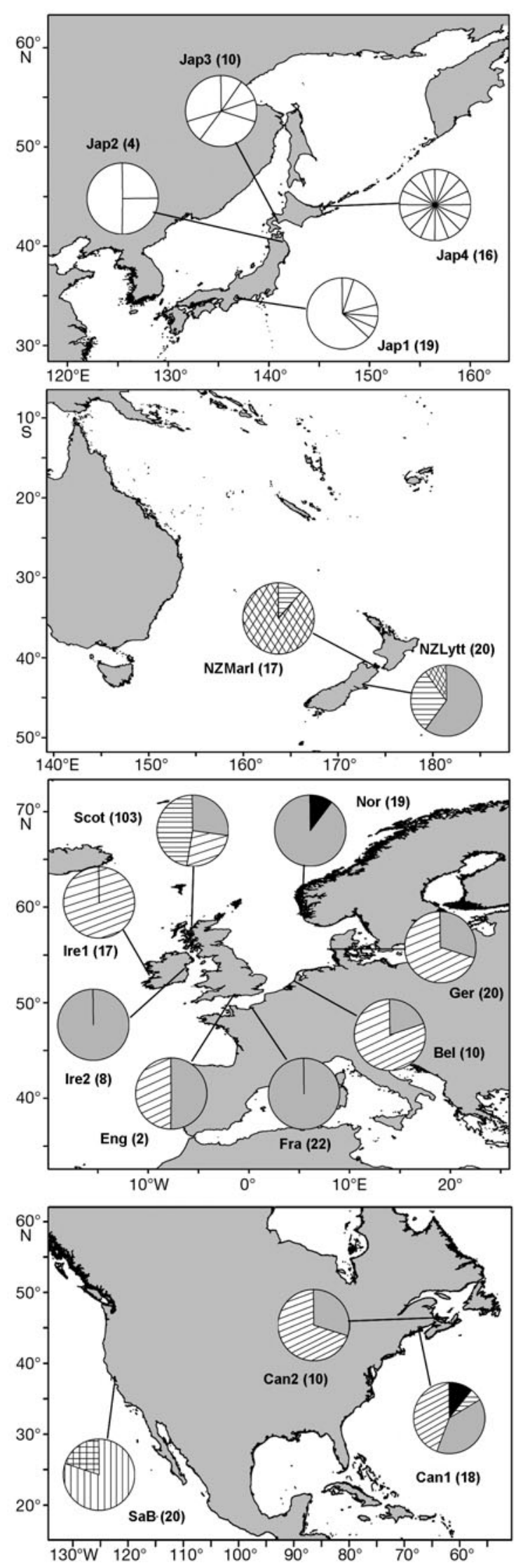

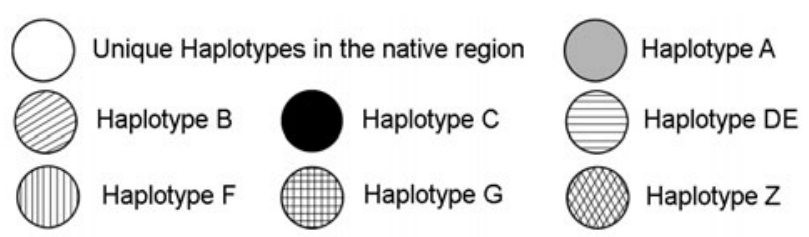

Fig. 4. Caprella mutica. Distribution of the 38 COI (cytochrome c oxidase subunit I haplotypes) of C. mutica in New Zealand and the Northern Hemisphere. Each site is represented by a pie chart showing population composition and relative haplotype frequency. Site codes correspond to Ashton et al. (2008b); numbers in parentheses indicate sample size. All haplotypes in the native range are unique to a single location, represented by white pie fill. Pie fill for non-native sites corresponds to the haplotype codes in Ashton et al. (2008b)

Magazine Bay Marina in December 2006; $98 \%$ of the females at the marina were gravid (Table 1). The proportion of brooding females was considerably lower on other sampling occasions, ranging from 0 to $39 \%$. There was a positive relationship between female size and the number of eggs in the brood pouch (range $=6$ to 54 eggs per female, mean $\pm \mathrm{SE}=24.3 \pm 1.6$ eggs per female; $y=4.487 x-25.134, \mathrm{n}=47$, Kendall's $\tau=0.57$, $\mathrm{p}<0.001$ ) for females from the Port of Lyttelton and the Marlborough Sounds combined. The proportion of juveniles in the populations was generally about 35\%, with extremes of 0 and $59.7 \%$ in the Port of Lyttelton in August 2008 (Table 1). Adult male C. mutica in the Port of Lyttelton and the Marlborough Sounds were significantly larger on average (mean length $\pm \mathrm{SE}=16 \pm 0.2$, maximum length $=34 \mathrm{~mm}$ ) than adult female $C$. mutica (mean length $=10.8 \pm 0.1 \mathrm{~mm}$, maximum length $=$ $16 \mathrm{~mm}$; Student's $t$-test, $t_{1,1400}=22.5, \mathrm{p}<0.001$ ).

The population structure of Caprella mutica sampled in the Port of Lyttelton on 27 August 2008 differed with habitat type. The fixed mooring pile supported a low population density comprising similar numbers of males and females, but no juveniles. Densities on floating tyre fenders and a vessel hull were considerably higher, and the proportion of males to females was similar (Table 1). Juveniles dominated the population on the vessel hull (59.7\% juveniles), while the population on the floating tyre fender in August 2008 comprised almost entirely adults $(94.4 \%)$. Between the 3 substrates, there were also significant differences in the size of adult $C$. mutica (ANOVA, $F_{2,341}=12.5, \mathrm{p}<$ 0.001), with adults largest on the vessel hull (mean length $\pm \mathrm{SE}=16.4 \pm 0.4 \mathrm{~mm}$ ), followed by the floating tyre fender $(14.5 \pm 0.4 \mathrm{~mm})$ and the fixed mooring pile $(13.7 \pm 0.7 \mathrm{~mm}$; Tukey-Kramer, $\mathrm{p}<0.05)$. Secondary substrata differed with habitat type, which may have influenced relative caprellid densities. For example, from single representative substratum samples, fixed 
Table 2. Pairwise comparisons of $F_{\mathrm{ST}}$ values for COI (cytochrome c oxidase subunit I) sequences of Caprella mutica from New Zealand populations and 15 sites in the native and non-native range. Site codes correspond with those in Fig. $4 .{ }^{*}$ Significant at $\mathrm{p}<0.05,{ }^{* *}$ significant at $\mathrm{p}<0.001$; statistical probabilities derived from 1054 permutations

\begin{tabular}{|c|c|c|c|c|c|c|c|c|c|c|c|c|c|c|c|c|}
\hline & Jap1 & Jap2 & Jap3 & Jap4 & Fra & Bel & Can1 & Can2 & Ire1 & Ire2 & Eng & Scot & Ger & Nor & $\mathrm{SaF}$ & NZLytt \\
\hline NZLytt & $0.509^{* *}$ & $0.362^{*}$ & $0.386^{* *}$ & $0.273^{* *}$ & $0.306^{* *}$ & $0.550^{* *}$ & $0.254^{* *}$ & $0.231^{*}$ & $0.742^{* *}$ & 0.187 & 0.213 & 0.052 & $0.293^{*}$ & $0.166^{*}$ & $0.865^{* *}$ & - \\
\hline NZMarl & $0.681^{* *}$ & $0.716^{*}$ & $0.616^{* *}$ & $0.453^{* *}$ & $0.940^{* *}$ & $0.880^{* *}$ & $0.735^{* *}$ & $0.844^{* *}$ & $0.949^{* *}$ & $0.908^{* *}$ & $0.858^{*}$ & $0.576^{* *}$ & $0.937^{* *}$ & $0.858^{* *}$ & $0.955^{* *}$ & $0.667^{* *}$ \\
\hline
\end{tabular}

mooring piles were dominated by solitary ascidians and filamentous red alga $(97$ and $3 \%$ DW, respectively), floating tyre fenders by filamentous red alga (100\% DW) and vessel hulls by erect bryozoans, solitary and colonial ascidians, filamentous red alga and hydroids $(47,28,23,1$ and $1 \%$ DW, respectively).

\section{DISCUSSION}

\section{Distribution and dispersal of Caprella mutica in New Zealand}

The specimens of Caprella mutica recovered from the Port of Timaru in February 2002 (Inglis et al. 2006a) are the first known occurrence of this species in New Zealand and the Southern Hemisphere, which is somewhat surprising given that the port is not a major shipping destination, with only a small number of relatively infrequent commercial ships arriving from overseas (Inglis et al. 2006a). For example, between 2002 and 2003, only 15 international commercial vessels visited the Port of Timaru (New Zealand Customs Service unpubl. data cited in Inglis et al. 2006a). Nine (60\%) arrived from Australia, 2 from the Northwest Pacific $(14 \%)$ and 1 each from the Arabian Sea and East Asia (14\%) (Inglis et al. 2006a). There are shipping routes connecting the Port of Timaru directly with the ports of Lyttelton, Dunedin, Napier and the Chatham Islands (Dodgshun et al. 2004). Of these, C. mutica has only been found in the Port of Lyttelton, which is $\sim 145 \mathrm{~km}$ north of Timaru on the South Island east coast. Lyttelton is a larger and busier port than Timaru, with international vessels arriving primarily from temperate regions of the Northwest Pacific, in particular Japan, Korea and China and southern Australia (Inglis et al. 2006b). For example, between 2002 and 2005, 654 international vessels arrived at the Port of Lyttelton from 44 different countries (Inglis et al. 2006b). The majority of overseas arrivals were from Australia (201), the Pacific Islands (141), the northwest Pacific (107) and Japan (76), but these were not necessarily the ports of origin.

The Port of Lyttelton is directly connected via shipping routes to most New Zealand ports (17 different ports were identified by Inglis et al. 2006b) and the Marlborough Sounds, where Caprella mutica has been found at 2 aquaculture sites in Pelorus Sound. There are relatively few vessel movements between the Ports of Lyttelton and Picton (in the Marlborough Sounds). However, 2 mussel harvesters periodically travel between the Port of Lyttelton and the Marlborough Sounds to service farms in the region, providing a slow-moving coastal transport route between the 2 regions (Gust et al. 2008).

In the Port of Lyttelton, Caprella mutica were first detected in the sea-chest of a commercial fishing trawler in April 2006, and then on the fouled hull of a private launch in Magazine Bay Marina, approximately $1 \mathrm{~km}$ southwest of the port. In September 2008, C. mutica was present on the hulls of 29 and $40 \%$ of the coastal fishing vessels and recreational vessels, respectively, moored in the port. Therefore, hull-fouling is and will continue to be an important transport vector in the future spread of the caprellid.

\section{Origins of New Zealand Caprella mutica}

Similar to non-native Caprella mutica in Europe and North America (Ashton et al. 2008b), there is a low level of genetic diversity in the New Zealand C. mutica populations. Only 3 haplotypes were found in the 2 New Zealand populations that were sampled. Of these, 2 haplotypes are of Atlantic origin and 1 is a new haplotype that is currently unique to New Zealand. Haplotype A, which occurs with high frequency in Atlantic C. mutica populations (Ashton et al. 2008b) was found only in the Port of Lyttelton. Haplotypes D and/or E which, respectively, are common in Scotland (Ashton 2006) and at one location in Canada (Ashton et al. 2008b), were present at both the Port of Lyttelton and the Marlborough Sounds. The unique New Zealand haplotype Z was present at both locations, but was more common in the Marlborough Sounds.

The slightly higher haplotype diversity in Lyttelton and the lower $F_{\mathrm{ST}}$ distances between this population and other globally distributed populations (particularly those in the native range) suggest that this may be the primary introduction site in New Zealand. A large 
number of individuals may have contributed to the founder population in a single introduction event, or several introduction events may be responsible for the increased genetic diversity here. The sharing of 2 haplotypes (only haplotype A was absent from Marlborough) between the 2 populations provides evidence of connections between them. In the absence of genetic information on Caprella mutica from Timaru, we cannot say whether the population in Timaru shares haplotypes common to those in the Port of Lyttelton and the Marlborough Sounds. It is possible that C. mutica in Lyttelton may have originated from Timaru where it was first detected in 2002, or from further afield, such as the Marlborough Sounds or overseas.

The absence of Caprella mutica in the Port of Lyttelton 2002 and 2004 baseline surveys (Inglis et al. 2006b) may be related to the sampling techniques used, differences in habitat type between the Ports of Timaru and Lyttelton and/or differential use of habitat in the 2 ports. Sampling for biofouling species in the baseline surveys involved taking wharf pile scrapings (Inglis et al. 2006b). In the Port of Timaru, C. mutica occurs in relatively high abundance on wharf piles, increasing the likelihood of detection in pile scrapings, whereas in Lyttelton, C. mutica occurs in very low abundance on wharf piles (present study, C. M. C. Woods pers. obs.). C. mutica was also found in benthic sled samples in Timaru, where there is often a reasonable amount of benthic drift algae and varied benthic substrata (e.g. algae-covered cobbles) which provide suitable habitat for the caprellid. In contrast, in Lyttelton the benthos is dominated by fine sediments with very little benthic drift algae (C. M. C. Woods pers. obs.). Thus C. mutica may have been present in Lyttelton prior to its first detection on a vessel hull in 2006, but was not actually detected during the baseline surveys. This raises the question as to whether C. mutica was present in other baseline survey ports and marinas, but was not detected due to the variables just discussed.

The dominance of the Atlantic haplotypes in the New Zealand populations suggests that Caprella mutica were introduced: (1) from non-native populations in the Atlantic, (2) directly from the same source population(s) in the native region as the Atlantic populations or (3) from populations that are as yet unidentified. Ashton et al. (2008b) identified 2 haplotypes that were unique to the Pacific coast of North America; however, they were not found in the New Zealand populations, but perhaps this is not surprising given that many of the ships arriving at the Port of Lyttelton have travelled from the Northwest Pacific and Australia (Inglis et al. 2006b). It is also interesting that haplotype $B$, which was almost as common in the Atlantic populations as haplotype A (Ashton et al. 2008b), was not present in the New Zealand populations.
Ashton et al. (2008b) found high genetic diversity in the native range, but none of the 31 native haplotypes were shared between the native locations or with the non-native populations. This continues to be the case despite the presence of a new haplotype in New Zealand. The dominance of only a few haplotypes in non-native Caprella mutica populations worldwide is intriguing. Is the reduced genetic diversity relative to the native range due to founder effects, erosion of genetic diversity during successive introduction events, or is it because only a limited number of haplotypes can survive in non-native habitats due to different selection pressures? It is also possible that selection during establishment of early non-native populations may have generated novel genotypes (Antonovics 1976a cited in Keller \& Taylor 2008), and it is these genotypes that are now establishing worldwide. The continuing absence of shared haplotypes between native and non-native $C$. mutica populations makes it difficult to elucidate this caprellid's invasion history and to unequivocally identify sources and introduction pathways.

\section{Population biology}

Populations of Caprella mutica in the Marlborough Sounds and the Port of Lyttelton exceeded 10000 ind. $\mathrm{m}^{-2}$ on all sample occasions, with the exception of the population on a mooring pile at Lyttelton (403 ind. $\mathrm{m}^{-2}$ ). These densities are within the range of those on artificial structures in Scotland, where densities in excess of 10000 ind. $\mathrm{m}^{-2}$ were recorded at 3 sites, with a summer maximum of approximately 319000 ind. $\mathrm{m}^{-2}$ at a fish farm site (Ashton et al. in press). On the island of Helgoland in the German Bight (North Sea), an annual average of 22000 ind. $\mathrm{m}^{-2}$ was recorded in an enclosed harbour (Boos 2009), and in British Colombia, Canada, densities on settlement plates ranged from 157 to 16159 ind. $\mathrm{m}^{-2}$ (Frey et al. 2009). Thus nonnative population densities are considerably higher than densities recorded from natural near-bottom habitat in C. mutica's native northeast Asia. In Possjet Bay, Sea of Japan, mean $( \pm \mathrm{SE})$ abundance ranged from $25 \pm 5.2$ ind. $\mathrm{m}^{-2}$ in spring (April) to $1223 \pm$ 89.7 ind. $\mathrm{m}^{-2}$ in summer (June) (Fedotov 1991), with a maximum of 2600 ind $\mathrm{m}^{-2}$ recorded by Vassilenko (2006) in the same bay. However, it must be noted that the New Zealand populations were, with the exception of 3, sampled in winter.

The seasonal spring peak in abundance and winter decline that was evident in Caprella mutica's native habitat (Fedotov 1991) and in European populations (Boos 2009, Ashton et al. in press) is not as apparent in the New Zealand populations. The highest abundance 
of C. mutica (184800 ind. $\mathrm{m}^{-2}$ ) in New Zealand was recorded in August 2007 (winter) on mussel lines at Waihinau Bay. The following summer, in February 2008, abundance had dropped to 46286 ind. $\mathrm{m}^{-2}$. In contrast, C. mutica disappeared from 3 of the 4 sites in Scotland during the winter months, and at the fourth site abundance declined to ca. 100 ind. $\mathrm{m}^{-2}$ in March (winter) (Ashton et al. in press). Water temperature may influence the regional differences seen in the seasonal cycle of abundance. The average water temperature in the native range can be as low as $0^{\circ} \mathrm{C}$ (Fedotov 1991) and, in Scotland, the minimum recorded water temperature during Ashton et al.'s (in press) population study was $7.4^{\circ} \mathrm{C}$. The lowest temperatures recorded in the Port of Lyttelton and the Marlborough Sounds were $8.7^{\circ} \mathrm{C}$ and $11.3^{\circ} \mathrm{C}$, respectively (Table 1).

The ratio of females to males was similar on most sample occasions, with females slightly more abundant on 2 occasions, and almost twice as abundant on the vessel hull sampled at Lyttelton in December 2006. Males were slightly more abundant than females on 3 occasions and almost twice as abundant as females in the Waihinau Bay population in June 2007. The general similarity in sex ratio and slight dominance of males in the New Zealand populations contrasts with sex ratios observed in the native range (Fedotov 1991) and in Scotland (Ashton et al. in press), where males were more abundant in summer. Juveniles were also abundant on all but 2 sample occasions, generally comprising over $30 \%$ of the population and, in the case of the vessel hull sampled in August 2008, reaching a maximum of $60 \%$ of the population. At Waihinau Bay, juvenile abundance was similar (32 to $38 \%$ ) regardless of season, with samples collected in May, August and February. Given that most of the populations were sampled in winter, the abundance of juveniles is somewhat surprising and contrary to Fedotov (1991) and Ashton et al. (in press), who found no or very few juveniles in winter. In Possjet Bay, Russia, the reproductive period extends from March to July, with juveniles appearing in May (Fedotov 1991), while in Scotland, juveniles were most abundant in spring and summer at one site and in summer and autumn at another 2 sites (Ashton et al. in press).

The fecundity of female Caprella mutica in New Zealand was considerably lower than that recorded by Ashton et al. (in press) in Scotland, with brood sizes ranging from 6 to 54, compared with 3 to 363 in Scotland. Given that female size is similar in the Scottish and New Zealand populations, this may be because most of the New Zealand samples were collected in winter. In New Zealand, the abundance of brooding females and juveniles during winter indicates continuous reproduction throughout the year, facilitating rapid population expansion and dispersal. Interest- ingly, the number of brooding females was actually lowest (5\%) in Waihinau Bay (Marlborough Sounds) in mid-summer (February 2008), and in early summer (November 2008) in Lyttelton (3\%). It is also worth noting that high numbers of brooding females were found on the 2 vessel hulls, with $98 \%$ of females brooding on the hull sampled in December 2006. Similarly, the population with the highest proportion of juveniles was on the hull sampled in August 2008. The differences in adult size, population structure and abundance between habitats in the Port of Lyttelton in August 2008 are probably related to differences in the attachment substratum and water movement. Caprellids favour highly branched substrata that allow encirclement by the pereopods (Ashton et al. in press), such as the filamentous red algae and erect bryozoans which dominated the floating tyre fenders and vessel hulls. C. mutica also appears to thrive on free-floating structures that are exposed to increased water movement, probably because food supply and water quality (i.e. oxygen supply) are enhanced with higher water flow and are more constant relative to shallow, fixed structures exposed to tidal variation.

\section{SUMMARY}

Since its discovery in New Zealand in the Port of Timaru in 2002, Caprella mutica has also become established in the Port of Lyttelton and the Marlborough Sounds. These are the first recorded occurrences of C. mutica in the Southern Hemisphere. Direct sequencing of the mtDNA COI gene indicates connectivity between the New Zealand populations, and higher haplotype diversity in the Port of Lyttelton suggests it may be the introduction site, with pathways operating either from the same source populations in the native region as Atlantic populations, from nonnative populations in the Atlantic or as yet unidentified populations. Preliminary data on the population biology of C. mutica in the Port of Lyttelton and the Marlborough Sounds indicate that the caprellid is well established. In contrast to native and non-native $C$. mutica populations in Europe, populations in $\mathrm{New}$ Zealand appear to occur in high densities in winter (>10000 ind $\mathrm{m}^{-2}$ ) and are reproductive year-round, with high numbers of juveniles and brooding females persisting throughout the winter months. Habitat also influences population structure; C. mutica was more abundant, larger and more fecund on floating than on fixed structures in the Port of Lyttelton in August 2008. Further surveys are required to monitor the range expansion of C. mutica in New Zealand and to investigate the effects of its invasion on both native and nonnative biota. 
Acknowledgements. Thank you to Dr. G. Ruiz, J. Hunt, A. Ormos, Dr. R. Pratt and the Smithsonian's Laboratories of Analytical Biology (LAB), Suitland, Maryland, USA, for assistance with the genetic analyses, and L. Peacock for Figs. $1 \& 2$. The assistance of the following NIWA (National Institute for Water and Atmospheric Research) personnel during field collections of Caprella mutica is gratefully acknowledged: D. Cairney, N. Davey, M. Kospartov, S. Miller, K. Neill, L. Peacock and K. Schimanski. Access to structures within the Port of Lyttelton was granted by the Lyttelton Port Company, and to fish and mussel farm sites in the Marlborough Sounds from The New Zealand King Salmon Company and Marlborough Mussel Company, respectively. Thank you to G. Fenwick for his comments on an earlier draft of this manuscript and the journal reviewers for their comments by which the manuscript was improved.

\section{LITERATURE CITED}

Altschul SF, Gish W, Miller W, Myers EW, Lipman DJ (1990) Basic local alignment search tool. J Mol Biol 215:403-410 Arimoto I (1976) Taxonomic studies of caprellids (Crustacea, Amphipoda, Caprellidae) found in the Japanese adjacent waters. Spec Pub Seto Mar Biol Lab 3:1-111

Ashton GV (2006) Distribution and dispersal of the non-native caprellid amphipod, Caprella mutica Schurin 1935. Unpublished PhD thesis, University of Aberdeen

Ashton GV, Willis KJ, Cook EJ, Burrows MT (2007) Distribution of the non-native Caprella mutica. Hydrobiologia 590:31-41

Ashton GV, Riedlecker EI, Ruiz GM (2008a) First non-native crustacean established in coastal waters of Alaska. Aquat Biol 3:133-137

Ashton GV, Stevens MI, Hart MC, Green DH, Burrows MT, Cook EJ, Willis KJ (2008b) Mitochondrial DNA reveals multiple Northern Hemisphere introductions of Caprella mutica. Mol Ecol 17:1293-1303

Ashton GV, Burrows MT, Willis KJ, Cook EJ (in press) Seasonal population dynamics of non-native Caprella mutica (Crustacea, Amphipoda) on the west coast of Scotland. Mar Freshw Res

Boos K (2009) Mechanisms of a successful immigration from north-east Asia: population dynamics, life history traits and interspecific interactions in the caprellid amphipod Caprella mutica Schurin, 1935 (Crustacea, Amphipoda) in European coastal waters. Unpublished PhD thesis, Freie Universität Berlin

Carlton JT (1979) Introduced invertebrates of San Francisco Bay. In: Conomos TJ (ed) San Francisco Bay: the urbanized estuary. Pacific Division of the American Association for the Advancement of Science, California Academy of Sciences, Golden Gate Park, San Francisco, CA, available at www.estuaryarchive.org/archive/

Carlton JT (1996) Biological invasions and cryptogenic species. Ecology 77:1653-1655

Cohen AN, Carlton JT (1995) Nonindigenous aquatic species in a United States estuary: a case study of the biological invasions of the San Francisco Bay and delta. NOAA, Siliver Spring, MD

> Cook EJ, Jahnke M, Kerckhof F, Minchin D, Faasse M, Boos K, Ashton G (2007) European expansion of the introduced amphipod Caprella mutica Schurin 1935. Aquat Invasions 2:411-421

Dodgshun T, Taylor M, Forrest B (2004) Human-mediated pathways of spread for non-indigenous marine species in New Zealand. Cawthron Report 700, prepared for the Department of Conservation. Cawthron Institute, Nelson Excoffier L, Laval G, Schneider S (2005) Arlequin version 3.0:

Editorial responsibility: Francesco Patti,

Naples, Italy an integrated software package for population genetics data analysis. Evol Bioinform Online 1:47-50

Fedotov PA (1991) Population and production biology of amphipod Caprella mutica in Possjet Bay, Sea of Japan. Biologiya Morya (Vladivost) 4:53-60

Felsenstein J (1985) Confidence limits on phylogenies: an approach using the bootstrap. Evolution 39:783-791

Frey MA, Gartner HN, Murray CC, Therriault TW (2009) First confirmed records of the non-native amphipod Caprella mutica (Schurin 1935) along the coast of British Columbia, Canada, and the potential for secondary spread via hull fouling. Aquat Invasions 4:495-499

Gust N, Inglis G, Floerl O, Peacock L, Denny C, Forrest B (2008) Assessment of population management options for Styela clava. MAF Biosecurity New Zealand Technical Paper No. 2009/04, MAF Biosecurity New Zealand, Wellington

Inglis G, Gust N, Fitridge I, Floerl O and others (2006a) Port of Timaru: second baseline survey for non-indigenous marine species (research project ZBS2000/04). MAF Biosecurity New Zealand Technical Paper No. 2006/02. MAF Biosecurity New Zealand, Wellington

Inglis G, Gust N, Fitridge I, Floerl O and others (2006b) Port of Lyttelton: second baseline survey for non-indigenous marine species (research project ZBS2000/04). MAF Biosecurity New Zealand Technical Paper No. 2006/01. MAF Biosecurity New Zealand, Wellington

Keller SR, Taylor DR (2008) History, chance and adaptation during biological invasion: separating stochastic phenotypic evolution from response to selection. Ecol Lett 11: 852-866

Laubitz DR (1970) Studies on the Caprellidae (Crustacea, Amphipoda) of the American North Pacific. Publications in Biological Oceanography no. 1, National Museum of Natural Sciences, Ottawa

Marelli DC (1981) New records for Caprellidae in California, and notes on a morphological variant of Caprella verrucosa Boeck, 1871. Proc Biol Soc Wash 94:654-662

Platvoet D, De Bruyne RH, Gmelig Meyling AW (1995) Description of a new Caprella species from The Netherlands: Caprella macho nov. spec. (Crustacea, Amphipoda, Caprellidae). Bull Zool Mus Univ Amst 15:1-4

Posada D, Crandall KA (1998) Modeltest: testing the model of DNA substitution. Bioinformatics 14:817-818

- Ronquist F, Huelsenbeck JP (2003) MrBayes 3: Bayesian phylogenetic inference under mixed models. Bioinformatics 19:1572-1574

Saiki RK, Gelfand DH, Stoffel S (1988) Primer-directed enzymatic amplification of DNA with a thermostable DNA polymerase. Science 239:487-491

Swofford DL (2002) PAUP*: phylogenetic analysis using parsimony. Sinauer Associates, Sunderland, MA

Vassilenko SV (1967) Fauna of Caprellidae (Amphipoda) of the Possjet Bay (Sea of Japan) and some data on their ecology. Issledovanija Fauny Morei (Explorations of the fauna of the seas of the USSR). Biotzenozy Zalika Possjet Japanskovo Morja 5:196-229

Vassilenko SV (2006) Caprellids. In: Adrianov EV (ed) Biota of the Russian waters of the Sea of Japan, Vol 4. Dalnauka, Vladivostok, p 74-132

Witt JD, Hebert PDN (2000) Cryptic species diversity and evolution in the amphipod genus Hyalella within central glaciated North America: a molecular phylogenetic approach. Can J Fish Aquat Sci 57:687-698

Zwickl DJ (2006) Genetic algorithm approaches for the phylogenetic analysis of large biological sequence datasets under the maximum likelihood criterion. $\mathrm{PhD}$ dissertation, University of Texas at Austin, TX

Submitted: June 5, 2009; Accepted: September 30, 2009

Proofs received from author(s): November 11, 2009 